\title{
Analysis of Sharia Performance Disclosures at Islamic Banks
}

\author{
Ahim Abdurahim \\ \{ahim@umy.ac.id) \\ Universitas Muhammadiyah Yogyakarta, Indonesia.
}

\begin{abstract}
The purpose of this study is to analyze the ability of financial statements prepared based on PSAK Syariah in disclosing information related to sharia performance. Research uses a qualitative approach and phenomenological techniques to analyze data. Data obtained by documentations, observations and interviews. Informants were selected using the purposeful and snow balling methods. The informants used were directors, managers, accounting staff at Bank Barakah Sejahtera, Sharia Supervisory Board, OJK supervisors and National Sharia Board. The results showed that the financial statements prepared based on the PSAK Sharia could be analyzed to measure financial performance but could not be analyzed to measure sharia performance. The results of this study provide recommendations to the Indonesian Sharia Accounting Standards Board to review the Basic Framework of the Preparation and Presentation of Sharia Financial Reports.
\end{abstract}

Keywords:

PSAK sharia, sharia performance, phenomenology, sharia bank

Article Received: 18 October 2020, Revised: 3 November 2020, Accepted: 24 December 2020

\section{Introduction}

Research on sharia entities is generally conducted on topics related to financial performance, disclosure of social performance and compliance with sharia principles, but research that examines the disclosure of sharia performance in sharia entity reports is rarely conducted. Research on financial performance on Islamic entities has been widely carried out by several researchers, such as research conducted by Ahsan (2016). The research was conducted to examine the financial performance of three Islamic banks selected in Bangladesh in 2007-20014. Using the CAMEL model of financial performance measurement the results of the study indicate that the performance of the three banks is strong. Research on financial performance in Islamic banks has also been carried out by Hanif, Tariq, and Tahir (2012). The study was conducted by comparing the financial performance of 5 Islamic banks and 22 conventional banks in Pakistan. The results showed that in terms of profitability and liquidity the performance of conventional banking was better, whereas in terms of financing risk management and solvency, Islamic banking was better.

Regarding the lack of research related to sharia performance of S. Ibrahim, Wirman, Alrazi, Nor, and Pramono (2004), argues that research on sharia performance is no less important than research on financial performance. This opinion is reinforced by Syafri Harahap (2003) which states that Muslim investors not only need information relating to financial indicators but also need information relating to sharia performance, namely information about conformity with sharia principles. Furthermore Syafri Harahap (2003) explains that in fact, the standards governing the disclosure of financial statements of sharia entities are incomplete, consequently the disclosure of financial statements for sharia entities uses the disclosure standards used in financial statements of conventional entities. Although AAOIFI has established accounting standards that include disclosure of financial statements, the resulting 
standards are still based on conventional accounting concepts.

Sharia performance research is a very important aspect, because if Islamic banks do not adhere to Sharia principles, the people will lose their trusty and will influence their decision to choose and continue to utilize the services provided by Islamic banks. Violations of Islamic banks to Sharia principles have a negative impact and cause people to leave the services of Islamic banks. Therefore, disclosure of sharia performance is important, sharia bank statements must provide information that can be analyzed to measure sharia performance (Syafri Harahap, 2003). This research was conducted considering the importance of Islamic bank statements present information that can be analyzed to measure financial performance and also measure sharia performance.

Financial reports that reveal complete, relevant and reliable information are important for stakeholders (W. H. W. Ibrahim, Ismail, \& Zabaria, 2011). Stakeholders will use information in financial statements for economic decision making. For Muslim investors, investment decisions are not solely emphasized on material benefits, but involve consideration of halal income. Because for every unlawful Muslim, the income is not in accordance with the principles of sharia (haram). In this regard, financial reporting on Islamic banks must have information that can be analyzed to assess compliance with sharia principles (sharia performance) (Abdurahim, Triyuwono, Mulawarman, \& Achsin, 2016b)

Disclosing complete and reliable information is important because there are differences in access to information between Islamic bank management and stakeholders (Fama \& Jensen, 1983). Based on Islamic values, all parties who are bound by a cooperation agreement must maintain trust. It is an obligation for management to provide adequate information for stakeholders to assess financial performance and performance of compliance with sharia principles. In this regard, Baydoun and Willett (2000) propose that the existence of Islamic values in Islamic banks encourages the need for Islamic Bank entities to disclose information relating to compliance with Islamic principles. Furthermore, Islamic banks must present information related to compliance with sharia principles (sharia performance). Baydoun and Willett (2000) propose a recommendation that Islamic banks must prepare financial reports that are in accordance with Islamic values called Islamic corporate reports (ICRs).

\section{Research Methods}

The purpose of this study is to analyze the ability of financial statements prepared based on PSAK Sharia in presenting information related to sharia performance. To achieve these objectives this research uses qualitative methods. Qualitative research is research that aims to explore a particular problem that is not measured by quantitative units (Creswell, 2013) The formulation of the theoretical framework relates to the meaning, awareness of spirituality and behavior inherent in individuals and groups in natural social environments (Morgan \& Smircich, 1980). This research was conducted in a natural setting to explore the behavior and activities of daily informants in the context of a social phenomenon (Morgan \& Smircich, 1980). The actions and behavior of informants are based on awareness and meaning according to the actors and in certain contexts (Fatchan, 2013).

Research uses phenomenology to analyze data. Phenomenology techniques attempt to identify the nature of human experience that appears on the surface of a particular phenomenon (Creswell, 2013). Researchers try to describe the symptoms that appear on the surface by making documentation and observation. Furthermore, by observation and in-depth interviews, researchers try to express the subject's experiences in everyday life. The conclusion of the study was built from information from the results of documentation, observations and interviews of informants related to the ability of financial 
statements prepared based on PSAK sharia in presenting and disclosing sharia performance

\section{Discussion and Result}

The initial stages of the study were carried out with a simple scenario. Using 5 banking financial statements published in national newspapers. Researchers used five banking financial statements, consisting of 2 conventional bank financial statements and 3 Islamic bank financial statements. The researcher covered the title and other identities that provided information about the bank's name and type of bank in the five financial statements. Furthermore, the five financial statements were shown to the informants namely, directors of Islamic banks, operational managers of Islamic banks, members of the National Sharia Board, supervisors of The Financial Services Authority (OJK) and Islamic economists. All informants were asked the same three questions by the same researcher in sequence, namely:

1. From the following five bank financial statements, identify which is the conventional bank financial statement and which is the Islamic bank financial statement?

2. From the following sharia bank financial statements, which financial statements have better financial performance?

3. From the following Islamic financial statements, which financial statement has better Islamic performance?

From these three questions, the answers obtained from the informants are as follows: related to the first question, all informants can easily identify which conventional bank financial statements and which Islamic bank financial statements by identifying elements of financial statements. If there are elements of financial statements that mention sharia products, the financial statements are sharia bank financial statements. According to researchers, all informants were able to identify differences in conventional financial statements and Islamic bank statements.

The second question, the informants from different backgrounds can analyze the financial performance of Islamic banks with many different features and different points of view. They mentioned the performance of Islamic banks better performance compared to other Islamic banks by looking at the amount of retained earnings, the amount of NPF, the amount of assets and other financial statement items. Although the informants did the analysis in different ways, the researcher concluded that basically the Islamic financial statements of the bank can present information that can be analyzed to measure the financial performance of the Islamic banks.

The informants' answers to the first and second questions with the third question are clearly different. Informants can answer the first and second questions relatively correctly, but none of the informants is able to explain and identify the sharia performance in Islamic banks to answer the third question. All informants agreed that the financial statements of the Islamic bank could not provide information that could be analyzed to measure the sharia performance. Based on the results of these tests, researchers strongly suspect that the financial statements presented by Islamic banks based on the PSAK Syariah do not provide adequate information related to sharia performance.

These findings are supported by other findings. Previously, researchers have identified two transactions consisting of one transaction according to sharia principles and the other is not according to sharia principles. Both transactions have been confirmed by the directors of the Islamic bank and the directors have the same assessment of the two transactions. Furthermore, the two transactions were confirmed by the accountant who prepared the Islamic bank's financial statements. The accountant states that there is no difference when recording transactions according to sharia principles and transactions not according to sharia principles. Furthermore, the accountant explained that the recording of debit or 
credit and the presentation of the two transactions are the same, and there is no distinction between conformity and non-compliance with sharia principles. These findings provide information that, if there are transactions that use contracts in accordance with sharia principles but their operations are not in accordance with sharia principles, there is no difference in recording or presentation in financial statements.

The existence of sharia-compliant transactions in sharia banks is recognized by the sharia supervisory board. Many factors have led to deviations from sharia principles, including the lack of understanding of the implementers, the low idealism of management and the economic motivation of the owners of Islamic banks (Abdurahim, Triyuwono, Mulawarman, \& Achsin, 2016a). In this regard, disclosure of the performance of sharia in Islamic banks is important, because it can be used as a means to assess the level of compliance with sharia principles.

Furthermore, based on further review of the Basic Framework for the Presentation and Preparation of Sharia Financial Statements (KDPPLKS), it was found that the definition of recognition and measurement did not differ significantly between the definition of recognition and measurement in the modern KDPPLK (IAI, 2009). This is not surprising if the process of recognition and measurement in sharia entities is no different from the process of recognition and measurement in conventional entities

\section{Conclusion, recommendation and limitation}

Based on the discussion and analysis of the information obtained, it can be concluded that the financial statements of Islamic banks prepared based on the PSAK Sharia cannot be used to assess the performance of sharia. That is because the process of recording transactions carried out by Islamic entities is no different from the transaction processes carried out by conventional entities. This happens because the definition of recognition and measurement in sharia PSAK does not have a significant difference with the definition of recognition and measurement in modern PSAK. Referring to the conclusion of this study, the researcher proposes a recommendation to DSAK at the Sharia Institute of Indonesia Chartered Accountant to conduct a review of the Basic Framework for the Presentation and Preparation of Sharia financial statements in order to be able to capture the reality of shariacompliant transactions and present them in sharia financial statements. Thus, Islamic bank financial statements can be used to assess Islamic performance.

The limitation of this study is that the analysis focused on the implementation of KDPPLKS and PSAK 101 on Sharia Entity Financial Statements. Further studies can be extended to other Islamic SFAS so that the study becomes more extensive and comprehensive

\section{Reference}

[1] Abdurahim, A., Triyuwono, I., Mulawarman, A. D., \& Achsin, M. (2016a). Akuntansi Syariah Holistis: Sebuah Refleksi dari Metode Dialektika Transendental dalam Perspektif "Aminullah". (Disertation). Universitas Brawijaya, Malang.

[2] Abdurahim, A., Triyuwono, I., Mulawarman, A. D., \& Achsin, M. (2016b). Aminullah: Revealing the Spiritual Values in Sharia Transaction. International Journal of Management and Administrative Sciences, 4(1), 65-73.

[3] Ahsan, M. K. (2016). Measuring financial performance based on CAMEL: A study on selected Islamic banks in Bangladesh. Asian Business Review, 6(1), \# 7-56.

[4] Baydoun, N., \& Willett, R. J. (2000). Islamic corporate reports. Abacus: A Journal of Accounting, Finance and Business Studies, 26(1), 71-90.

[5] Creswell, J. W. (2013). Penelitian Kualitatif dan Desain Riset (A. L. 
Lazuardi, Trans. S. Z. Qudsy Ed. 1 ed.). Yogyakarta: Pustaka Pelajar.

[6] Fama, E. F., \& Jensen, M. C. (1983). Agency problems and residual claims. The journal of law and Economics, 26(2), 327349.

[7] Fatchan, A. (2013). Metode Penelitian Kualitatif: 10 Langkah Penelitian Kualitatif Pendekatan Konstruksi dan Fenomenologi. Malang: UM Press.

[8] Hanif, M., Tariq, M., \& Tahir, A. (2012). Comparative performance study of conventional and Islamic banking in Pakistan. International Research Journal of Finance \& Economics(83).

[9] IAI. (2009). Financial Accounting Standard: Framework for the Preparation and Presentation of Islamic Financial Statements In. Jakarta: Salemba Empat.

[10] Ibrahim, S., Wirman, A., Alrazi, B., Nor, M., \& Pramono, S. (2004). Alternative disclosure and performance measures for Islamic banks. Paper presented at the Second Conference on Administrative Sciences: Meeting the Challenges of the Globalization Age, King Fahd University of Petroleum \& Minerals, Dhahran, Saudi Arabia.

[11] Ibrahim, W. H. W., Ismail, A. G., \& Zabaria, W. N. W. M. (2011). Disclosure, risk and performance in Islamic banking: a panel data analysis. International Research Journal of Finance and Economics, 72, 100-114.

[12] Morgan, G., \& Smircich, L. (1980). The Case of Qualitative Research. Academy of Management Review, 5(4), 491.

[13] Syafri Harahap, S. (2003). The disclosure of Islamic values-annual report. The analysis of Bank Muamalat Indonesia's annual report. Managerial Finance, 29(7), 70-89. 